Japanese Research in Business History 2012 | 29

\title{
Reorganization of the Mold Manufacturing Production System in the First Half of the High-Growth Era
}

\author{
Tsutomu Hirayama \\ Tokyo Metropolitan University
}

\section{Introduction}

I

$\mathrm{N}$ THIS PAPER, I discuss the reorganization of the production system in the moldmanufacturing sector in the first half of the high-growth era, focusing primarily on the plastic mold industry (the "mold industry") in the Tokyo area. Part of the interest in discussing this topic lies in the rapid increase in productivity in the moldmanufacturing sector during this period. Due to limited demand, manufacturers before the high-growth era were relegated to an existence as subcontractors to the assembly industry. Indeed, the manufacturing industry at the time was in many ways a form of "second floor basement production" in the plastics industry. ${ }^{1}$ The system in place relied on versatile skilled laborers to respond flexibly to all orders, an adaptability characteristic of the demands in single-part production. Moreover, the production method used machine tools such as lathes and drilling machines only for parts machining and materials processing but chisels, files, and other manual tools for grooving and finishing. ${ }^{2}$ However, the arrival of the highgrowth era brought about great change in the mold market. Because of the

1. Kanto Plastic Mold Association, Kumiai no ugoki [Association activities] 9 (Tokyo: Kanto Plastic Mold Association, 1959), 27.

2. Kanto Plastic Mold Association, Kantō purasuchiku kanagata kumiai setsuritsu kankei shiryō [Materials on the establishment of the Kanto Plastic Mold Association] (Tokyo: Kanto Plastic Mold Association, 1958). 
rapid development in the assembly industry, there was a strong demand for increased production from mold manufacturers. However, as I will discuss later, process control issues and a lack of versatile skilled labor posed significant obstacles. The manufacturing industry responded by exploring new production systems that reduced reliance on versatile skilled labor. As I will show below, these changes in the first half of the high-growth era triggered broad reorganization initiatives in the production system of the manufacturing industry.

While some past research has examined the development of capital investment in the manufacturing industry during this time, ${ }^{3}$ scholars have not addressed the relationship between development in capital investment and the reorganization of the production system in the manufacturing industry. In order to grasp more fully the process by which manufacturers responded to growing demand, it is necessary to clarify how improved machinery impacted the production system. Treating this question will help explain the role that the mold sector played in supplying the key tools ("mother tools") to the assembly industry, which fueled contemporary economic growth.

Through these topics and perspectives, I will concentrate on three main themes, keeping in mind the relationships with developments in improved facilities and machinery. First, I will discuss the factors that drove the restructuring of the production system that developed in the plastic mold industry in the first half of the high-growth era. I will also look at the conditions that predicated the changes. Finally, I will explore the production system that emerged as a result.

Before continuing to the main discussion, I will provide a brief description of what "molds" are. Molds are the metal shapes that help form materials into given configurations, providing a useful production means for shaping large quantities of products with uniform quality and thereby laying much of the foundation for modern large-scale production. They are indispensable to assembly industry production in automobiles

3. Seiichirō Yonekura, "Seifu to sangyō no dynamikusu: Sangyō seisaku no sofuto na sokumen" [Government-industry dynamics: The soft side of industrial policies], Hitotsubashi kenkyū nenpō 33 (1993): 249-292; Naoki Taguchi, Nihon kanagata sangyō dokuritsusei no kiban [The foundation of the independence of the Japanese mold industry] (Kanazawa: Department of Economics in Kanazawa University, 2001); Tsutomu Hirayama, "Kōdoseichōki zenhan no kanagata seizōgyō ni okeru setsubi tōshi dōkō" [Capital investment trends in mold manufacturing during the first half of the high-growth era], Rekishi to keizai 197 (2007). 
and household appliances, products for which Japan is well known, and have a significant impact on quality and precision in these industries. Molds can be categorized into two main types: "dies" (an open type that has an opening and a high extrusion load) and "molds"(a closed type that has a relatively low extrusion load and forms materials in a closed space). Typically, the former is for press dies, while the latter is for plastic molds. This paper will focus on the industry that manufactures plastic molds. In the mold industry, there are two types of manufacturers: manufacturing companies that create the molds they use in-house and direct sales vendors that manufacture molds exclusively for direct sale. However, in the plastic mold industry, in-house molds were relatively scarce during the highgrowth era, with direct-sale molds representing $70 \%$ of the total production value. Considering the characteristics of the mold manufacturing industry as a base sector in high-volume production, it would be no exaggeration to say that the mold manufacturing industry in the high-growth era and particularly developments in the plastic mold industry treated in this paper - influenced developments in assembly industries at the time. My discussion approaches developments in the contemporary manufacturing industry by examining the process by which the production system of the plastic mold industry in the Tokyo area was restructured.

\section{The Integrated Control Production System and the Expansion of the Mold Market}

In the mid-1950s, manufacturers employed an integrated control production system called the "tatewari system." This system was a method of mold production whereby all processes from design to completion were assigned within a "group unit...centered on skilled laborers who were cultivated through an apprentice system." production system" discussed later differs fundamentally in terms of work organization, as design and other aspects of production were divided into specialized processes, each assigned to different workers according to this division of labor. In the integrated control production system shown in Figure 1, the company president oversaw the work performed in all work processes, which were distributed among the lower ranks according to

4. Kanto Plastic Mold Association, Kaizen seika kiroku hikae [Copy of improvement result records] (Tokyo: Kanto Plastic Mold Association,1961). 
length of service. ${ }^{5}$ Laborers were not fixed to each assignment but rather relocated based on the difficulty of the various work processes (design $>$ finishing/assembly $>$ [marking-off $>$ machining $>$ machine engraving] $>$ materials processing), experience, and worker availability. The method ultimately allowed each laborer to learn the skills needed to engage in all processes. ${ }^{6}$ The mold manufacturing industry thus developed a production system in which a number of workers assisted in different tasks around a skilled laborer who could vertically supervise the entire mold manufacturing process (the company president).

Figure 1: Work organization of companies using the integrated control production method (1963)

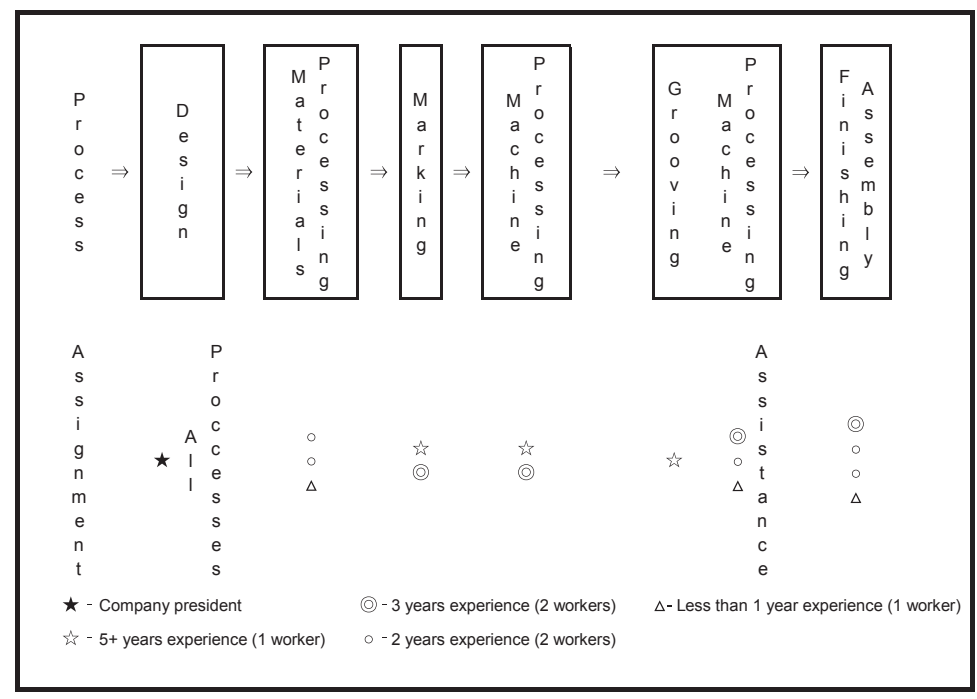

Source: Tokyo Metropolitan Government, Purasuchiku kanagata kōgyō no jittai bunseki [Analysis of conditions in the plastic mold industry] (Tokyo: Tokyo Metropolitan Government, 1964).

Part of the reason why this system came about was that in the mold manufacturing industry, most products were made to order. Thus, workers needed flexible skills to meet the unique configuration demands of each product. As companies also had to assemble the manufactured parts, a

5. Tokyo Metropolitan Government, Purasuchiku kanagata kōgyō no jittai bunseki [Analysis of conditions in the plastic mold industry] (Tokyo: Tokyo Metropolitan Government, 1964), 38.

6. Interview with Kuroyanagi, former president of Meiki \& Company, Ltd. , August 27, 2004. 
system with one skilled laborer and the surrounding group did a better job of reducing assembly errors that a setup in which technicians who differed in experience and skill levels oversaw each process.

This system also suited the trends of the plastic mold market in the mid-1950s. In the years leading up to 1955 , mold production value was 975 million yen (in 1953) and 1.12 billion yen (in 1954). ${ }^{7}$ The mold market was extremely small and the increasing pace of production limited, with configurations confined to relatively simple compression molds such as knobs and utensils used in the manufacture of light electronic appliances or general merchandise. ${ }^{8}$

The manufacturing industry for the market at the time was dominated by individually operated small businesses with an average of 3.8 workers in 1953 and 4.6 workers in 1954 . $^{9}$ Workers used failing, aging lathes and drilling machines $(46.7 \%$ of all machines in 1954) to create molds based on sketches described as "hastily scrawled plans indiscernible to all but one craftsman." ${ }^{, 10}$ Under these production conditions, only versatile skilled laborers possessed both the necessary drafting and machining skills.

However, in the high-growth era, the plastic mold market underwent a sweeping transformation. After the mid-1950s, the establishment of the petrochemical industry, in addition to development of the assembly industry, brought with it domestic thermoplastic resin, which was not only cheap and highly moldable but also claimed a diverse set of properties, thus rapidly saturating the plastic products market. ${ }^{11}$ This in turn rapidly boosted production values in the mold industry from 975 million yen in 1953 to 2.24 billion yen in 1959 and 7.05 billion yen in $1964 .{ }^{12}$ Although injection molds were more difficult to produce than compression molds,

7. Japan Productivity Center, Kanagata [Molds] (Tokyo: Japanese Productivity Center, 1957).

8. Hisashi Koyama, Nihon purasuchiku kōgyō shi [A history of the Japanese plastics industry] (Tokyo; Kōgyō chōsakai, 1970), 419.

9. Kanto Plastic Mold Association, Einen kinzokusha meibo 1958-1972 [Roster of longservice employees](Tokyo: Kanto Plastic Mold Association).

10. Kazuo Namegawa, Meiki to tomoni tsuribashi o ayumu [Walking the suspension bridge with Meiki] (Tokyo, 2000), 126.

11. Koyama, 419.

12. Japan Die \& Mold Industry Association, Kanagata seisan chōsa hōkokusho [Mold production research report] (Tokyo: Japan Die \& Mold Industry Association, 1961); Ministry of International Trade and Industry (MITI), Kikai tōkei hyō [Machinery statistics] (Tokyo: MITI, 1960). 
demand for injection molds skyrocketed in the 1960s as the material for injection molds - thermoplastic resin - established a steady supply. The high-percentage distribution of injection mold sales for mold manufacturers began to eclipse compression molds from 1957 to 1960, reaching $82 \%$ overall in $1964 .^{13}$

The relationship between market scale and the production system was no longer favorable, and mold manufacturers began to rethink the conventional integrated control production system.

\section{Issues with the Rise in Labor Demand}

When faced with the expansion of the mold market, as described above, many mold manufacturers responded in the late 1950s by expanding their scope of business with an enlarged workforce. The average number of laborers per plastic mold manufacturer in the Tokyo area increased from 3.8 in 1953 to 14.5 in 1964 . This expansion was particularly remarkable in the mid-1950s, more than doubling from 5.7 to 11.7 between 1955 and $1959 . .^{14}$

The age distribution of the workforce at the end of the decade also drew a stark contrast with the conditions in the mid-1950s. If we assume that it would take at least ten years to cultivate a versatile labor force, the age of 25 would be a reasonable age standard (assuming workers could amass ten years of experience after graduating from junior high school). ${ }^{15}$ In 1953, laborers aged 25 years and older occupied $56 \%$ of the labor force, a ratio that declined steadily through the 1950 s to $38 \%$ in $1960 .{ }^{16}$ The distribution of laborers expected to have relatively more years of experience dropped significantly, while laborers under the age of 25 occupied a larger part of the distribution.

The transformation of labor distribution in the integrated control production system was a contributing factor to labor-related issues for mold manufacturers, particularly difficulties in process control and the

13. Tokyo Metropolitan Government, Purasuchiku kanagata seizōgyō jittai chōsa hōkokusho [Plastic mold manufacturing field survey report] (Tokyo: Tokyo Metropolitan Government, 1965), 18.

14. Kanto Plastic Mold Association, Einen kinzokusha meibo.

15. The versatile labor force discussed later was stated to take "between 4-5 and up to 10 years" to cultivate; therefore, the baseline was demarcated at 25 years old, the age a person would be after graduating from middle school and spending 10 years at the company.

16. Kanto Plastic Mold Association, Einen kinzokusha meibo. 
exposure of a stretched skilled labor force. Under the integrated control production system, companies could boost manufacturing capacity through increased labor by 1) increasing number of laborers within a manageable scope of the process control manager; and/or 2) securing a versatile labor force to increase the unit of production. Many manufacturers opted for the latter because a larger versatile labor force would most likely directly contribute to production growth; however, increases in the versatile labor force also meant larger production lines and more managers, a negative side that was problematic for operators.

The case of Meiki \& Company, Ltd. spotlights the production control difficulties in a system centered on the "premodern production method... or skilled workers cultivated through an apprentice system" that "made orderly production through modern process control methods very difficult." 17 The result, the company stated, was that it "hesitated to expand production scale by increasing the number of employees and modernizing machinery... and could not meet demands for precision, large-scale orders, and reduced delivery times as the modern plastic industry developed." 18 The situation no longer allowed for passive expansion of production under an integrated control production system that hinged on versatility.

Additionally, the supply of versatile skilled laborers was extremely restricted ${ }^{19}$ because it took "between $4-5$ years and up to 10 years" to train someone in all the necessary processes by reallocating positions. ${ }^{20}$ Although largely latent in the mid-1950s, when market growth was mild, this problem materialized into "technician poaching" when the decline in the distribution of laborers aged 25 and older left a dearth of skilled workers in the field.

In February 1958, nearly all the mold manufacturers in the Tokyo area banded together to form the Kanto Plastic Mold Association. ${ }^{21}$ As members circulated and shared information, the situation became clear. The "technician poaching" was part and parcel of the manufacturing sector

17. Kanto Plastic Mold Association, Kaizen seika kiroku hikae.

18. Ibid..

19. Interview with Kuroyanagi, former president of Meiki \& Company, Ltd. , August 27, 2004.

20. Kanto Plastic Mold Association, Kumiai no ugoki 17 (Tokyo,1961), 33.

21. Kanto Plastic Mold Association, Kantō purasuchiku kanagata kumiai setsuritsu kankei shiryō. 
at the time due to the relatively high-skilled work involved; ${ }^{22}$ however, during this period, "poaching" occurred frequently among processing and mold manufacturers." Recently, there have been cases of technician poaching among association members, ${ }^{23}$ the Association noted, indicating that the situation had escalated to a level where members of the same group recognized their poachers. This poaching behavior was prominent within the Kanto Plastic Mold Association, and members quickly moved to develop countermeasures in May 1958 at the first committee meeting after the Association's formation. With agreement from the Association members, leaders announced a ban on poaching among members. ${ }^{24}$ Nevertheless, the situation became so serious that Company $\mathrm{N}$ performed wide-scale "technician poaching" on Company P in September 1959.

\section{Production System Reorganization and Provisions for Technical Requirements}

Faced with problems related to skilled workers brought on by mold market expansion after the mid-1950s, mold manufacturers began searching for an alternative to the integrated control production system.

For example, Umeda, Ltd. and Meiki \& Company, Ltd., discussed above, attempted to address this problem by hiring human resources familiar with process control methods in other industries where production control methods were further developed. Umeda, Ltd. hired Shigeo Ishikawa for this role, while Meiki \& Company, Ltd. brought on Isamu Suzuki, Kazuo Gomikawa, and Kimio Takabe. ${ }^{25}$ Ishikawa was manager of the Mukōjima Plant Engineering Production Division 4 at Sumitomo Bakelite Co., Ltd.. After retiring in April 1957, he began working for Umeda, Ltd. in August of the same year. Meiki \& Company, Ltd. President Katsutarō Kuroyanagi, on the other hand, hired Suzuki, Gomikawa, and Takabe through their acquaintanceship at Tokyo Keiki Inc. in anticipation of future organizational improvements after establishing Meiki \& Company, Ltd. in 1948. Suzuki was hired in 1949 after working at Eiwa

22. Namegawa, Meiki to tomoni tsuribashi o aуuтu, 100.

23. Kanto Plastic Mold Association, Kumiai no ugoki 2 (Tokyo, 1958), 15; Kanto Plastic Mold Association, Kumiai no ugoki 9 (Tokyo, 1959), 33-45.

24. Kanto Plastic Mold Association, Kumiai no ugoki 2 (Tokyo, 1958), 15.

25. Kanto Plastic Mold Association, Kaizen seika kiroku hikae. 
Seiki, Ltd., Nihon Kōkū Heiki, Ltd., and Tokyo Keiki Inc. Gomikawa was hired in 1951 after working at Kyōsan Electric Manufacturing Co., Ltd. and Jidōsha Buhin Seizō Kabushikigaisha (Automotive Parts Manufacturing, Ltd.). Takabe, meanwhile, was hired in 1948 after working at Tokyo Keiki Inc. As I will discuss later, these men were central to organizational improvements at the two companies.

The Kanto Plastic Mold Association implemented plant visits to advanced companies, which also stimulated organizational changes among manufacturers. ${ }^{26}$ The Association began plant visits in 1958 soon after its establishment, and the visits involved advanced business operations in other industries, as well, such as Hitachi and large mold manufacturers in Kanto and Kansai. ${ }^{27}$ The focal points were machinery conditions and labor management at the advanced businesses, as well as process control methods.

However, in order to introduce these new process control methods, there were inadequacies in technical requirements to overcome. These included the segmentation/specialization of the design process and improvements in mold production machinery.

In order to enhance their design capabilities, companies needed to make a departure from rough sketches based on intuition and experience. At the time, the only people who could accurately understand the configuration and precision of molds and parts in these plans were their drafters. These drafters, skilled laborers at the center of production, were thus the only people able to understand the molds being produced. Therefore, mold production based on rough sketches was a factor that bolstered the authority of skilled workers.

As previously stated, manufacturers were producing molds using partly limited and failing machinery in dire need of improvement. In many cases, companies used this poor machinery due to a reliance on experience and skill. In other words, it was impossible for just anyone to use these machines and achieve the same precision, which made skilled workers absolutely necessary. This provided structural support for a production

26. Kanto Plastic Mold Association, Kumiai no ayumi: Sōritsu 10 shūnen kinen [The history of the association: $10^{\text {th }}$ anniversary] (Tokyo: Kanto Plastic Mold Association, 1968), 16.

27. Kanto Plastic Mold Association, Unei iinkai shiryō [Operations committee materials] (Tokyo: Kanto Plastic Mold Association, 1958-1959); Kanto Plastic Mold Association, Kumiai no ugoki 11 (Tokyo,1960), 63. 
method dependent on skilled workers and was one factor that made it difficult to dismantle this process. In order to form a new production system, manufacturers had to convert to machinery that could achieve precision irrespective of the user's skill level.

The conditions for overcoming restrictions rapidly fell into place after the mid-1950s with the expansion of the mold market. The rising demand for injection molds provided the opportunity. An example of this is the following sequence of events from when injection molds were first ordered at Meiki \& Company, Ltd. through their improvements on technical requirements.

Injection molds were first ordered at Meiki \& Company, Ltd. in 1956, when the company received an inquiry about molds for toys from U.S.based National Merchandising Co. just as it was earnestly beginning injection mold production. ${ }^{28}$ In 1962, injection molds occupied $90 \%$ of the company's annual production value of 197.8 million yen. ${ }^{29}$

Due to the injection mold orders, the company could no longer deliver products with the "hastily scrawled plans indiscernible to all but one craftsman" as they had before. What the manufacturer needed were "plans (mold plans) to be made for every part that other craftsmen in the plant could understand. ${ }^{30}$

That is why the company hired vocational school graduate Akito Ayukawa and Yoshiaki Tamura, an employee of Sumitomo Bakelite Co., Ltd., one of the company's counterparties, in 1956 to draw up plans aimed at solidifying its design system. In 1958, the company recruited Yoshihiro Masui, Toshihiko Hōjō, Sumio Itō, and others through a newspaper posting and positioned them under Akito Ayukawa as design personnel. ${ }^{31}$ In the end, "a division of labor for molds was achieved...by putting the shapes and values on paper for plans that were drawn in the heads of plant craftsmen." 32

Meanwhile, references indicate that, compared to the compression molds that controlled the market in the past, injection molds had more

28. Namegawa, Meiki to tomoni tsuribashi o ayumu, 124.

29. Tokyo Metropolitan Government, Purasuchiku kanagata kōgyō no jittai bunseki, 20.

30. Namegawa, Meiki to tomoni tsuribashi o ayumu, 126. Note that the injection mold distribution for the company was $85.5 \%$ in 1960 (Tokyo Metropolitan Government, Purasuchiku kanagata kōgyō no jittai bunseki, 23).

31. Namegawa, Meiki to tomoni tsuribashi o ауити, 126, 163.

32. Ibid., 163. 
parts and came in more complex configurations; ${ }^{33}$ therefore, "as high precision was demanded in molds, high grade machinery such as milling machines and copy diesinking machines became necessary." ${ }^{34}$ Looking at the exact catalog of machinery at the company after $1956^{35}$ shows one shaper and one metal sawing machine for materials processing, four lathes and five drilling machines for parts processing, four milling machines (including copying tools) for milling processing, and one grinder for grinding processing. While increasing the number of machines from six in 1953 to 21 in 1958, the company also filled out its inventory of machines, focusing on machine processing. This reduced the difficulty of mold processing and expanded the possibilities of replacing refined skills.

The example of Meiki \& Company, Ltd. presents a good model for other mold manufacturers facing skilled labor force problems in that it demonstrates the requirements for reorganizing the production system. Actually, looking at an investigation conducted by the Kanto Plastic Mold Association in 1963, all companies that received orders for injection molds ${ }^{36}$ had employed design engineers out of high school or college and planned a departure from the traditional design mode, which was discernible to experienced workers only. These companies sponsored new employee training and lectures for their designers. Hokushin Mold Engineering Co., Ltd. even used an educational system to teach plan drafting and other related topics. Employment figures for new graduates in $1963^{37}$ show that junior high school graduates accounted for $70 \%$ of the total, whereas high school, vocational school, and university hires were minimal. Given these employment trends, companies sought to hire better-educated laborers and school them while establishing their design departments.

Looking at the development of equipment in 1954, the mold manufacturing industry claimed 82 machine tools in total but then began

33. Hirayama, 17.

34. Gōsei Jushi Shinbun, April 15, 1959.

35. Kanto Plastic Mold Association, Kanagata kōgyō jittai chōsa hyō [Mold industry field survey data] (Tokyo: Kanto Plastic Mold Association, 1963); Kanto Plastic Mold Association, Tokyo-to chūshōkigyō kaizen seika kenshō kōhosha kankeishorui [Documents on candidates for honors bestowed by the Tokyo Metropolitan Government for improvements in small and medium-sized companies] (Tokyo: Kanto Plastic Mold Association, 1961).

36. Kanto Plastic Mold Association, Kanagata kōgyō jittai chōsa hyō.

37. Tokyo Metropolitan Government, Purasuchiku kanagata seizōgyō jittai chōsa hōkokusho (calculated based on 1964 figures). 
to develop rapidly in 1959, eventually reaching 711 in 1962 and 1,055 in $1964 .{ }^{38}$ In baseline terms, companies that had 20 or more workers (21 in all), which produced $89 \%$ of all injection molds in $1964,{ }^{39}$ were each equipped $^{40}$ with an average of 2.63 machines in 1954, 11.58 in 1959, 24.05 in 1962, and 36.00 in 1964. The breakdown of machine types shows that from $60 \%$ of machines for parts processing in 1954, the numbers went to 2.1 machines for materials processing, 5.0 machines for parts processing and 2.0 machines for milling in 1959, and came in at 4.7, 9.2, and 4.3 machines, respectively, in $1962 .{ }^{41}$ This is indicative of the remarkable advancement and diversification of machines in companies with 20 or more workers, which tended to cater to injection mold orders, as they rolled out serious capital investment after the mid-1950s.

\section{Reorganization of the Production System and Its Effects}

\section{The Spread of the Division of Labor System}

The organization and management of production plants were completely transformed by the specialization of design plan processes, the introduction of high-precision machinery, and the education dedicated to them. Because Umeda, Ltd. and Meiki \& Company, Ltd. were able to resolve control issues and stride ahead in their reorganization initiatives, the industry as a whole quickly reorganized the overall production system. What production method did these manufacturers substitute for the integrated control production system? Below, I discuss the examples of reorganization at Umeda, Ltd. and Meiki \& Company, Ltd. in closer detail.

Umeda, Ltd. and Meiki \& Company, Ltd. reorganized in 1957 and 1958, respectively. ${ }^{42}$ Umeda, Ltd.'s reorganization was characterized by 1) establishing design and process divisions among the technology divisions to oversee plan drafting, and 2) setting up four mold production groups, with groups 1, 2, and 3 divided as work groups and group 4 serving

38. Ibid..

39. Tokyo Metropolitan Government, Purasuchiku kanagata seizōgyō jittai chōsa hōkokusho, 18.

40. Tokyo Metropolitan Government, Purasuchiku kanagata seizōgyō jittai chōsa hōkokusho (calculated based on 1965 figures).

41. Companies with fewer than 20 workers totaled 254 machines with 9.1 machines per company.

42. Kanto Plastic Mold Association, Kaizen seika kiroku hikae. 
as an assistant group to the work groups. The former created plans for everything from production assembly to individual parts, which formed the basis for the production flow, increased product precision, and reduced delivery time. This made it simple for "even regular workers to understand each part and create molds requiring guidance from skilled workers only for complex tasks." The result succeeded in allowing groups 1, 2, and 3 to concentrate on cavity sections (the sections of the product that are shaped), which represent the most important part of mold manufacture, while the assistant group (group 4) performed relatively simple duties, such as parts or materials processing. If the company determined that the delivery schedule had to be adjusted at a weekly Monday production meeting, the assistant group (group 4) would be merged with groups 1, 2 and 3 to meet deadlines.

Meiki \& Company, Ltd., on the other hand, established a design division primarily with university and technical high school graduates to do away with the rough sketches based on intuition and experience. Production processes fell into two divisions: one divided by machine for materials processing (shaper), cavity processing (milling), and parts processing (lathe), and the other divided by occupation for finishing processing. This division of labor tended to leave versatile experienced laborers with the task of finishing the machining performed by the less experienced laborers who outnumbered them. ${ }^{43}$ The company set up roundtable discussions to gather opinions from employees and group leaders in order to establish a common understanding and reduce errors in transfers between divisions. Under this work organization, the operations division unified production controls that had once been supervised by versatile experienced laborers.

The reorganization in both companies involved dividing the production processes that were in the hands of one group into multiple divisions (a division of labor system). This shifted the authority of process control formerly assigned to versatile workers to the side of the company or operators, while less experienced workers tasked with secondary duties were assigned to machine and materials processing in hopes of improving work efficiency. However, it is important to note that the reorganization implemented by both companies did not purely dismantle the skilled 
system and replace it with a single-skill worker system. The specialization of the drafting process and improvements in machinery freed skilled workers from the relatively simple tasks of drafting and machine processing; by assigning them mainly to finishing processes, which required experience more than any other step in the mold production system, they could fully apply their more sophisticated skills.

The issue of an insufficient labor force was overcome at the beginning of the 1960s with the spread of the division of labor system, with one observer saying, "Despite having a lot of work at the time, it was impossible to rapidly cultivate experienced workers. Thus, many companies turned to the yokowari method to divide tasks." ${ }^{, 4}$ According to a survey in the Tokyo area in 1960, the nine of the 14 companies surveyed used the yokowari division of labor system, with all nine adopting it in the early $1960 \mathrm{~s}^{45}$ One interesting thing about the companies ${ }^{46}$ that used the method was that the smallest employed 12 workers. In companies with around 10 workers, the method essentially had no design division; instead, the company president drafted plans, and processes were divided into machining and finishing pieces. By covering the two prerequisites previously discussed - improving and specializing design skills and equipment improvements - each company was thus able to reorganize in a way it found suitable.

\section{Effects of Using the Division of Labor System}

Using the division of labor system had several effects on mold manufacturers.

First, I will examine Meiki \& Company, Ltd. to compare the company before and after its reorganizations. ${ }^{47}$ Following the reorganization at Meiki \& Company, Ltd. in 1958, there were also reforms in 1959 and 1961. The reforms in 1959 set up a division within the design division to oversee the research and development of mold design and techniques. In 1961, the groups divided by machinery and duties, as tradition dictated, were divided into six divisions (operations, technology, development,

44. Gōsei Jushi Shinbun, December 17, 1962.

45. Tokyo Metropolitan Government, Purasuchiku kanagata kōgyō no jittai bunseki, 37.

46. Tokyo Metropolitan Government, Purasuchiku kanagata kōgyō no jittai bunseki, 4546.

47. Kanto Plastic Mold Association, Kaizen seika kiroku hikae. 
machinery, finishing, and process control) to clarify the boundaries of responsibility further. Additionally, the division that expanded into Design Division 1 in 1959 now acted as a technical division that oversaw mold designs and technical negotiations with other divisions. The division that grew into Design Division 2 in 1959 became the development division and took charge of researching and developing mold techniques, researching heat treatment techniques, and maintaining records.

Sources indicate that at the company, "measuring control in each division was thorough, while the progress of work and the feasibility of deadlines were no longer estimated by intuition but rather indicated specifically by calculation." In Figure 1 above, which represents an organizational chart of companies using integrated control production control, comparatively inexperienced laborers worked at the relatively simple task of materials processing, whereas a handful of experienced workers handled more important processes. This implies that the division of labor developed from within work apportioned within group duties. However, the resolution of process-specific issues and work balancerelated issues between processes in the division of labor according to group duties would have depended on the ability of experienced workers to recognize those issues. For example, there were duty teams that comprised several groups; if these duty teams had gaps in production capacities, the gaps would be recognized as group problems. The gap in discovering problems by process is where the division of labor system and integrated control production system greatly differ. This is how the division of labor system clarifies an approach for resolving issues and allows the measuring control of each division to be thorough. This was a factor in the continuing process of discovering and correcting issues at Meiki \& Company, Ltd. after the first reorganization.

A comparison of the production values of the company between the years it reorganized and the preceding years reveals growth from 233.4 million yen in 1957 to 329.4 million yen in 1958 (the first reorganization); from 329.4 million yen in 1958 to 449 million yen in 1959 (the second reorganization); and again from 697.4 million yen in 1960 to 964.4 million yen in 1961 (the third reorganization). The production values per worker changed from 6.86 million yen to 6.72 million yen; from 6.72 million yen 7.74 million yen; and from 9.18 yen to 9.64 million yen over the same 
periods. ${ }^{48}$ This shows that, with the exception of the first reorganization, production value and production value per worker increased as a result of reorganization.

An examination of the labor organization under which this increase in production value occurred shows that the number of workers younger than 25 for the changed from 18 to $27 ; 27$ to 33 ; and 41 to 52 over the same periods, while the number of workers aged 25 and older changed from 11 to $16 ; 16$ to 17 ; and 18 to $24{ }^{49}$ The number of young laborers at the company is worth noting. The number of workers younger than 25 increased by nine during the first reorganization, whereas the number of workers aged 25 and older increased by only five. Still, the production value per worker decreased by 140,000 yen while production capacity per person stayed more or less constant. This is why the company eventually showed an increase of 119.7 million yen in production value along with the increase in laborers.

This suggests that the increase in the number of young workers under the division of labor system sustained worker productivity rather than lowering it. In fact, when we look at the relationship between machine utilization rates and the use of the division of labor system for the entire mold manufacturing industry (including non-plastic mold companies) in the mid-1960s, we see that the machine utilization rate for companies of 1-19 workers was between $65 \%$ and $70 \%$. Companies with $20-49$ workers achieved a level around $75 \%$, and companies with 50 or more workers had a machine utilization rate of over $80 \%{ }^{50}$ A comparison between companies with fewer than 20 workers and companies with 20 or more workers (many of which used the division of labor system) shows that machine utilization rates were from $5 \%$ to $15 \%$ higher in companies with 20 or more workers. The same survey shows that the percentage of workers who had been employed for less than five years was $60.5 \%$ in companies that used the division of labor system and $57.0 \%$ in companies that used the integrated

48. Kanto Plastic Mold Association, Tokyo-to chūshōkigyō kaizen seika kenshō kōhosha kankei shorui.

49. Kanto Plastic Mold Association, Kyūjintaisaku to teichakushidō no gutaiteki hōsaku ni tsuite [Recruitment policies and specific measures aimed at establishment] (Tokyo: Kanto Plastic Mold Association, 1969); Kanto Plastic Mold Association, Einen kinzokusha meibo.

50. Japan Society for the Promotion of Machine Industry, Kanagata kōgyō kōzō chōsa hōkokusho [Research report on the structure of the mold industry] (Tokyo: Japan Society for the Promotion of Machine Industry, 1965), 83. 
control production system. ${ }^{51}$ In other words, the division of labor system was capable of maintaining a higher machine utilization rate than the integrated control production system despite having labor forces with essentially the same levels of experience.

Table 1, which compares labor productivity between plastic mold manufacturers using the division of labor system and those using the integrated control production system, illustrates several interesting points. Although the number of workers and machinery cost per worker is roughly the same, Company G (23 workers/approximately 220,000 yen in machinery cost per worker/division of labor system) has a lower machinery cost per worker than Company B (18 workers/approximately 290,000 yen in machinery cost per worker/integrated control production system) but still manages to attain higher gross profits, higher net profits, and a lower worker expenditure to gross profit ratio. Comparing Companies A and $\mathrm{C}$, which have similar machinery costs, shows that company $\mathrm{C}$ has a lower worker to gross profit ratio. Companies B, C, and D have roughly the same fixed assets per worker, but profits per worker are higher in Companies $\mathrm{C}$ and $\mathrm{D}$, which use the division of labor system but have lower expenditures per worker than Company B. This would suggest that workers at companies that use the division of labor system achieve higher productivity than laborers in integrated control production systems at the same machinery costs; this productivity in turn ties into increased net and gross profits and lower worker expenditure to gross profit ratios.

The results above confirm that through the division of labor system, companies were able to achieve higher productivity even with the injection of a less experienced workforce. For manufacturers frustrated by the length of time required to cultivate experience in the face of rapidly expanding demand in the latter half of the 1950s, this system thus afforded an effective means for utilizing an increasingly younger work force in less time. Looking at the industry as a whole, the spread of the division of labor system in the first half of the high-growth era helped the mold industry develop divisions with higher production efficiency compared to levels in the mid-1950s.

51. Ibid., 87; Ministry of International Trade and Industry (MITI), Kanagata seizōgyō jittai chōsa hōkokusho [Mold manufacturing field survey report] (Tokyo: MITI, 1966), 186. 


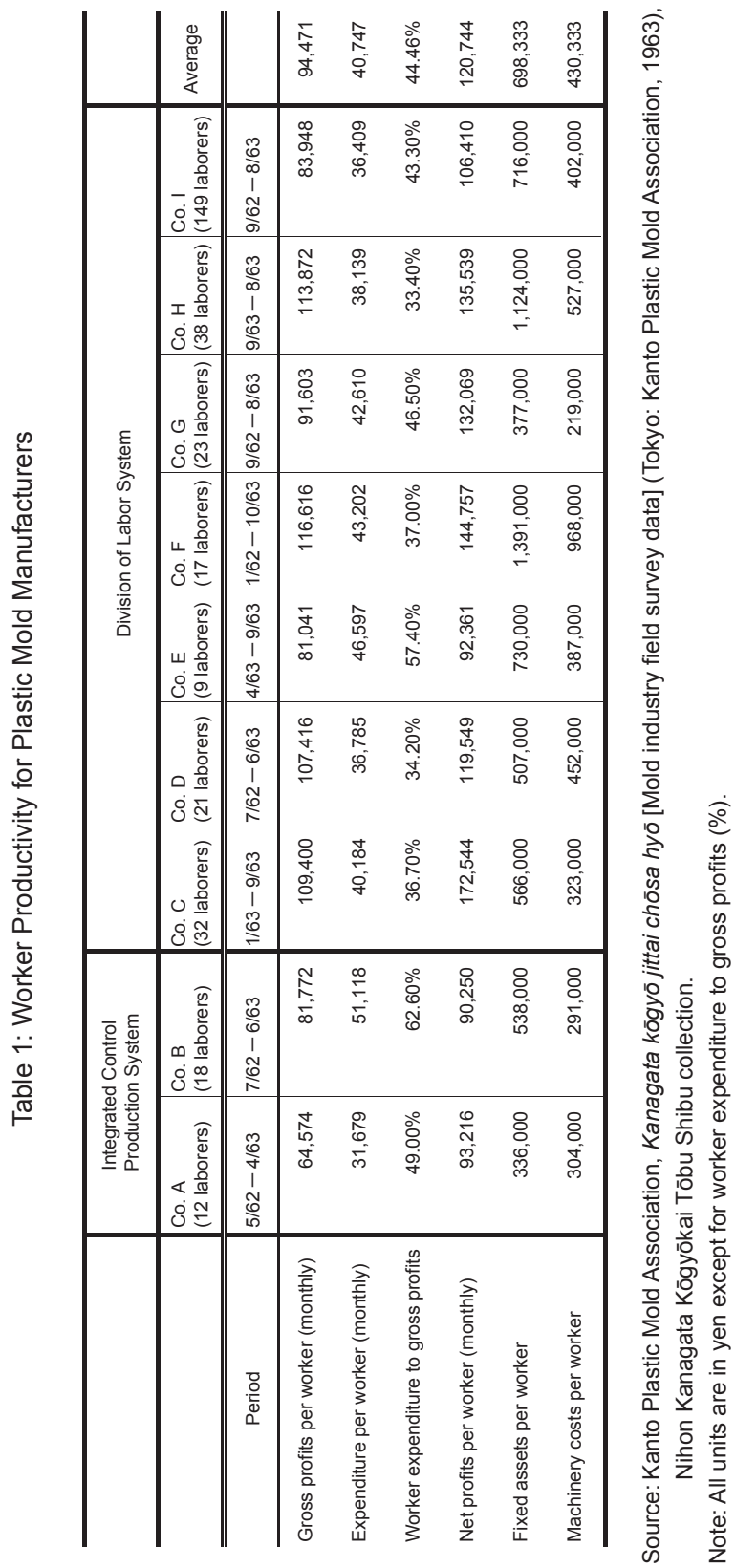




\section{Conclusion}

This paper focused on plastic mold manufacturers in the Tokyo area, looking at the factors that necessitated a process-spanning division of labor system, the course of the system's spread, and the effects of its adoption.

The biggest factor behind the adoption of this division of labor system was the lack of an experienced workforce that emerged with the expansion of the mold market. Under the integrated control production system, which employed a cultivation method designed to train the labor force in all processes, developing experience took time and prevented the system from keeping pace with rapid market expansion. At the same time, it exposed process control problems that arose out of relying on an experienced labor force as pressure grew for productivity improvements. Thus, mold manufacturers began searching for a production system to utilize a young, inexperienced labor force and broke away from a production system dependent on experienced labor.

Capital investment that began to increase quickly in the latter half of the 1950s had a large impact on the new system. With the introduction of new and powerful machines, companies began to see the possibilities of substituting technology for experience in machine processing. The result was a division of the versatile experienced work force and a reorganization of the labor force in a way that applied experience and skills in each process in the manufacturing industry. Due to certain unique characteristics, however, the mold manufacturing industry was unable to replace the experienced work force with a single-skill work force. The versatile experienced work force was concentrated in design and finishing processes that required experience, which effectively applied their experience and skills and therefore achieved productivity improvements. In other words, the division of labor formed a new experienced labor force that specialized in processes rather than simply dismantling experience and proficiency.

The division of labor system was more efficient than the integrated control production system and allowed for production expansion through the hiring of a young labor force. In this way, manufacturers transitioned to a more productive system while overcoming issues of experience in the labor force. Considering the characteristics of the mold manufacturing industry - which was a base sector of the high-volume production industry 
- from the perspective of raising standards throughout the manufacturing industry as a whole, the development of the division of labor system spread a production system that increased labor productivity, thus increasing the mold supply capacity for the entire manufacturing industry.

\section{Bibliography}

Hirayama, Tsutomu. "Kōdoseichōki Zenhan no Kanagata Seizōgyō ni Okeru Setsubi Tōshi Dōkō" [Capital Investment Trends in Mold Manufacturing During the First Half of the High-Growth Era]. Rekishi to keizai 197 (2007).

Taguchi, Naoki. Nihon Kanagata Sangyō Dokuritsusei no Kiban [The Foundation of the Independence of the Japanese Mold Industry]. Kanazawa: Department of Economics in Kanazawa University, 2001.

_. Sangyō Gijutsu Kyōsōryoku to Kanagata Sangyō [Industrial Technology Competitiveness and the Mold Industry]. Kyoto: Minerva Shobō, 2011.

Yonekura, Seiichirō. "Seifu to Sangyō no Dainamikusu: Sangyō Seisaku no Sofuto na Sokumen" [Government-industry Dynamics: The Soft Side of Industrial Policies]. Hitotsubashi kenkyū nenpō 33 (1993). 